Boletín de la Sociedad Geológica Mexicana

VOLUMEN 67, NÚM. 1, 2015, P. 45-57

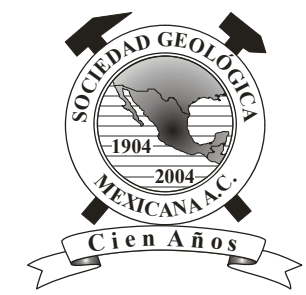

\title{
Berriasian-early Valanginian calcareous shallow-water facies from the Arperos Basin: A proposal from the foraminiferal assemblage of the clasts of the Guanajuato Conglomerate, central Mexico
}

\author{
Lourdes Omaña ${ }^{1, *}$, Raúl Miranda-Avilés ${ }^{2}$, María Jesús Puy-Alquiza ${ }^{2}$ \\ ${ }^{1}$ Instituto de Geología, Universidad Nacional Autónoma de México, Ciudad Universitaria, Delegación Coyoacán, 04510, México, \\ D.F., México. \\ ${ }^{2}$ Departamento de Minas, Metalurgia y Geología, Universidad de Guanajuato, Ex-Hacienda de San Javier, 36020, Guanajuato, Gto., \\ México. \\ *lomanya@geologia.unam.mx
}

\begin{abstract}
The Eocene Guanajuato Conglomerate is composed of clasts derived from igneous and metasedimentary sources that can be related to the Upper Jurassic-Lower Cretaceous arc and back-arc assemblages of the El Paxtle and Arperos Basin. Limestone clasts contain a shallow-water platform fauna that includes bivalves, brachiopods, gastropods, echinoderms and foraminifers. Foraminiferal studies were carried out on these limestone clasts. The benthic foraminiferal association is composed of Pseudocyclammina lituus (Yokoyama, 1890); Everticyclammina virguliana (Koechlin, 1942); Montsalevia salevensis (Charollais, Brönnimann and Zaninetti, 1987); Neotrocholina valdensis (Reichel, 1955); Andersolina cherchiae (Arnaud-Vanneau, Boisseau and Darsac, 1988); Neotrocholina molesta (Gorbatchik, 1959); Pfenderina neocomiensis (Pfender, 1938); Nautiloculina bronnimanni Arnaud-Vanneau and Peybernès, 1978; Hechtina praeantiqua Bartenstein and Brand, 1949; Protopeneroplis cf. P. banatica Bucur, 1993; Istriloculina sp., Moesiloculina sp., Protomarsonella sp., Ammovertellina sp. and Glomospira sp.

The Tethysian foraminiferal assemblage observed in the limestone clasts indicate the age of the calcareous source as Berriasianearly Valanginian, which is the age of the deposition within the Arperos Basin.

The occurrence of these shallow-water limestone clasts suggests the existence of a shallow-water platform deposit located in the Arperos Basin. This is significant considering that all previous work focused on the deep-water sedimentary rocks (siliciclastic and calcareous). Thus, these clasts are a key to reconstructing the depositional history and architecture of this basin.
\end{abstract}

Keywords: Tethysian benthic foraminifera, Berriasian-early Valanginian, Guanajuato Conglomerate.

Resumen

El Conglomerado Guanajuato del Eoceno se compone de clastos derivados de rocas de fuentes ígneas y metasedimentarias que pueden estar relacionadas con los conjuntos del Jurásico Superior-Cretácico Inferior de arco y tras arco del Paxtle y la Cuenca Arperos. Los clastos de caliza contienen una fauna de aguas someras de plataforma que incluye bivalvos, braquiópodos, gasterópodos, equinodermos y foraminíferos. Se realizó el estudio de los foraminíferos bentónicos en estas calizas, la asociación se compone de Pseudocyclammina lituus (Yokoyama, 1890); Everticyclammina virguliana (Koechlin, 1942); Montsalevia salevensis (Charollais, Brönnimann y Zaninetti, 1987); Neotrocholina valdensis (Reichel, 1955); Andersolina cherchiae (Arnaud-Vanneau, Boisseau y Darsac, 1988); Neotrocholina molesta (Gorbatchik, 1959); Pfenderina neocomiensis (Pfender, 1938); Nautiloculina bronnimanni Arnaud-Vanneau y Peybernès, 1978; Hechtina praeantiqua Bartenstein y Brand, 1949; Protopeneroplis cf. P. banatica Bucur, 1993; Istriloculina sp., Moesiloculina sp., Protomarsonella sp., Ammovertellina sp. y Glomospira sp. 
El conjunto de foraminiferos tethysianos observados en los clastos de caliza indican la edad de la fuente calcárea en el BerriasianoValanginiano temprano, que es la edad del depósito en la Cuenca de Arperos.

La presencia de estos fragmentos de calizas de aguas someras sugiere la existencia de un depósito de plataforma somera ubicada en la cuenca de Arperos, es significativo teniendo en cuenta que todo el trabajo previo se centró en las rocas sedimentarias de aguas profundas (siliciclásticas y calcáreas). Por lo tanto estos fragmentos son clave en la reconstrucción de la historia deposicional y arquitectura de esta cuenca.

Palabras clave: Foraminiferos bentónicos tethysianos, Berriasiano-Valanginiano temprano, Conglomerado Guanajuato.

\section{Introduction}

Eocene continental successions are exposed in the Mesa Central of Mexico (Figure 1). These successions unconformably overlie sheared and folded rocks of the Mesozoic and are in turn overlain by Eocene-Oligocene volcanic rocks of the Sierra Madre Occidental (Edwards, 1955; Aranda-Gómez and McDowell, 1998).

The Eocene continental successions of Central Mexico received different names depending on the locality of the outcrop. In Guanajuato (Figure 1), these continental rocks are designated Guanajuato Conglomerate (GC) (Botsford, 1909; Edwards, 1955; Aranda-Gómez and McDowell, 1998). The GC was first mapped and described by Wandke and Martínez (1928). Later, Guiza (1949) and Edwards (1955) divided the GC into two units, the lower and the upper member, separated by an unconformity.

The GC is 1500 to $2000 \mathrm{~m}$ thick (Edwards, 1955) and is composed of limestone, granite, andesite, metasediments, diorite and pyroxenite clasts that indicate the erosion of uplifted blocks of the basal complex of the Sierra de Guanajuato (Arperos Basin). According to Martini et al. (2011), the Arperos basin was "developed in a back-arc setting and evolved from continental to open oceanic conditions from the Late Jurassic to the Early Cretaceous."

The dating of the GC is difficult due to the fact that few fossils have been found. Edwards (1955) recorded small vertebrate bones collected from thinly laminated siltstone within the lower part of the GC. A part of a skull of a tiny rodent more like Taxymys (Middle Eocene) was found. Later, Ferrusquía-Villafranca (1987) dated the GC as midlate Eocene age, based on the mammal remains (Viverravus sp. and Apheliscus) recovered from the lower member.

Edwards (1955) stated that one cobble contains well-preserved silicified corals identified as Stylina (Heliocoenia) sp., Myriophyllia sp., the M. trinitatis group and Drandraraea, and assigned these fossils preliminarily to the Lower Cretaceous but they could possibly be as old as Late Jurassic. Other cobbles of fossiliferous limestone contain eroded sections of corals, pelecypods and bryozoans.

Based on the information reported by Edwards (1955), we are particularly interested in investigating the clasts that contain the shallow-water assemblage.

The objective of the investigation was to conduct a benthic foraminiferal study in order to determine the age and the paleoenvironmental and paleobiogeographical significance of these microfossils found in the limestone clasts.

The benthic foraminifera are stratigraphically useful in the shallow-water environment; the comparison with the biostratigraphic ranges based on them, established mostly in Tethysian basin, enables an accurate dating of the studied foraminiferal assemblage.

In this paper we present data about the specific composition of the foraminiferal assemblage in the limestone clasts that indicate they are derived from a carbonate platform. In addition, taking into account the coarseness, the features, and the present distribution of the GC clasts, it can be assumed that these materials were derived from a source near the city of Guanajuato as previously stated (Edwards, 1955).

\section{Geological setting}

The Sierra de Guanajuato is located in the southern Mesa Central (Figure 1). The basal complex is composed of the Guanajuato arc and Arperos Basin (Freydier et al., 1996; Martini et al., 2011).

The Upper Jurassic-Lower Cretaceous Guanajuato arc assemblage is made up of an intrusive complex and a cogenetic eruptive succession. The intrusive complex is made up of gabbro, diorite and tonalite, locally intruded by basaltic and dolerite dike swarms, with scarce wehrlite and olivine clinopyroxenite grading transitionally to interlayered clinopyroxene and metagabbro. The eruptive succession is composed of pillow basalt and hyaloclastite interbedded with volcanic breccia, radiolarian chert, arkose, arkosic greywacke, and scarce rhyodacitic tuff at the top of the sequence (Lapierre et al., 1992; Ortiz Hernández et al., 1992). The Guanajuato arc has been interpreted as an intraoceanic arc constructed on ocean crust (Lapierre et al., 1992; Tardy et al., 1991).

The El Paxtle assemblage (Martini et al., 2011) is comparable to the arc assemblage described by Lapierre et al. (1992) and consists of the El Paxtle and Tuna Manza Formations.

Rocks of the arc assemblage overthrust the Arperos 

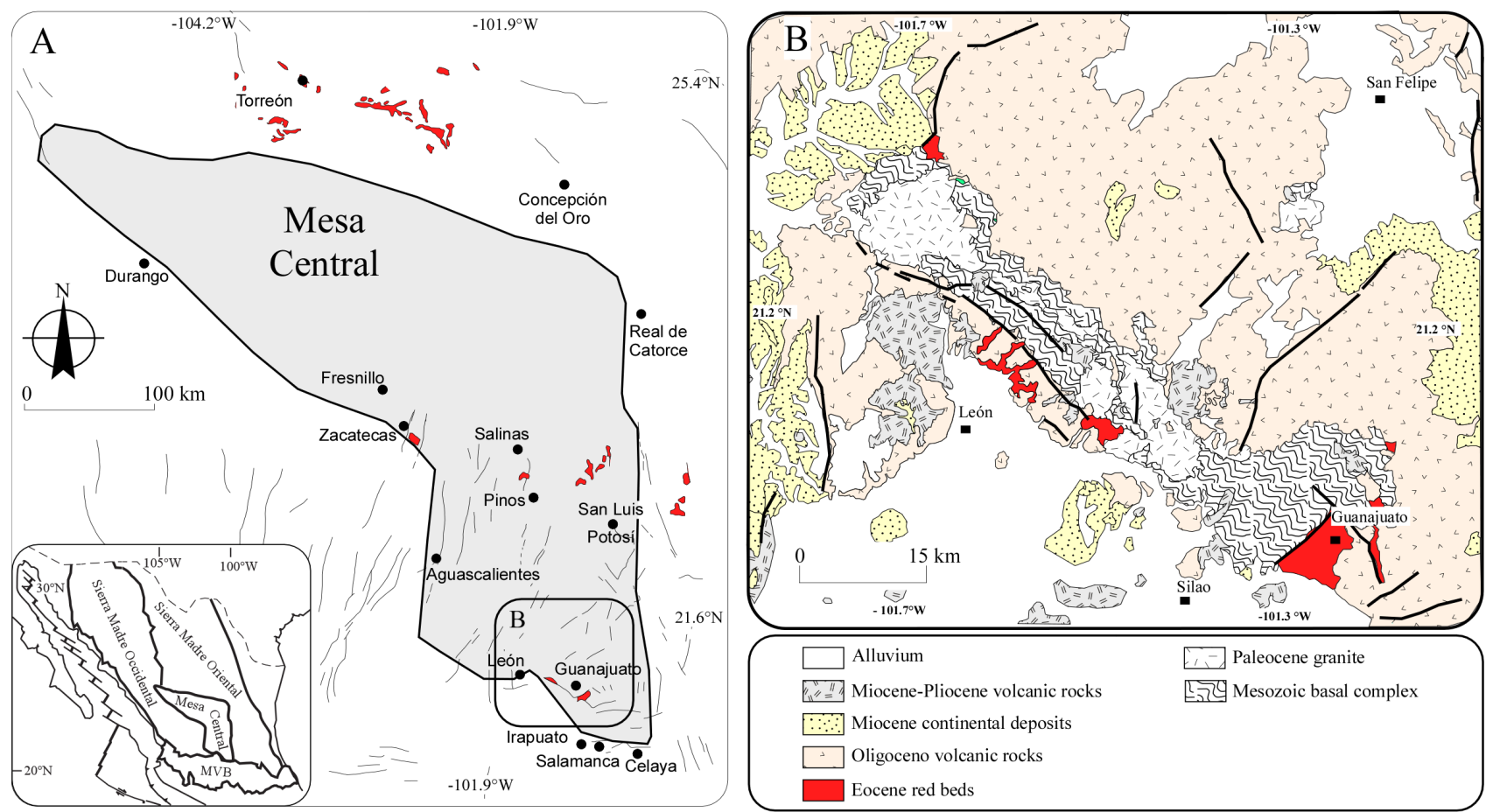

Figure 1. Geographic and geological map.

Basin assemblage, which consists of the Arperos and the Esperanza formations. The Esperanza Formation has been described as polydeformed metavolcaniclastic rocks and limestone (Echegoyén-Sánchez, 1978).

The Arperos Formation is composed of $120 \mathrm{~m}$ of pillow basalt hyaloclastite, radiolarian chert, and cherty shale overlain by finely bedded laminated turbidites arranged in a pile of imbricated kilometric scale nappes bounded by mylonitic shear zones (Martini et al., 2011). This unit has been dated by whole-rock K-Ar of the pillow basalts to span between 93 and 85 My (Ortiz Hernández et al., 2003). In contrast, it has been assigned a Valanginian-Turonian age based on radiolaria (Dávila-Alcocer and Martínez-Reyes, 1988); and a Tithonian-Valanginian age established from a nanofossil study (Corona-Chávez, 1988) has been reported from the sedimentary rocks overlying the pillow basalt.

Martini et al. (2011) considered the Esperanza Formation to be a petrotectonic assemblage made up of a volcanosedimentary succession divided into two formations, the Esperanza and the Valenciana formations.

Rocks of the arc and Arperos Basin assemblages were folded and thrust partially metamorphosed under lowgrade greenschist conditions and covered by Albian neritic limestone of the Perlita Formation (Chiodi et al., 1988). The available data permit more solid support of the closure of the Arperos Basin in the upper Aptian. Chiodi et al. (1988) provided an upper limit (Albian) from fossils in the $\mathrm{La}$ Perlita Formation. Martini et al. (2011) assigned a lower limit from detrital zircons (118 My).

Volcanic and plutonic activity, as well as sedimentation periods, occurred in the Cenozoic (Nieto-Samaniego et al., 1996; Hernández-Silva et al., 2000). Thus the GC has been interpreted as a continental molasse deposited on topographic plains, associated with post-Laramide faulting orogeny (Aranda-Gómez and McDowell, 1998).

The Losero Formation unconformably covers the GC and is considered the base of the volcanic succession of Oligocene age. The Losero Formation is composed of lithic arkose to litharenite sandstones (Puy-Alquiza et al., 2013). Aranda-Gómez and McDowell (1998) suggest a volcaniclastic origin and Randall et al. (1994) propose a volcanic origin deposited in lacustrine conditions.

\section{Material and methods}

The limestone clasts studied in this work come from the lower member of the GC (Figure 2).

Conglomerate compositions were determined in 12 outcrops, counting pebble populations. In each outcrop 200 pebbles were counted using the method of Dürr (1994). Fifty-two limestone clasts were collected and analyzed by polarized microscope. The benthic foraminifera in the thin sections were observed under a petrographic microscope. Microphotographs were taken with a digital camera.

\section{Results}

\subsection{Guanajuato Conglomerate composition}


The GC unconformably overlies the basal complex and is overlain by Cenozoic volcanic rocks. It is interpreted as coalescing alluvial fans deposited at the base of a fault-bounded mountain block (Edwards, 1955; ArandaGómez and McDowell, 1998). The GC has been divided into two members (Edwards, 1955). The lower member is composed of polymictic conglomerates with an erosive base intercalated with red sandstone layers and andesitic lavas at the base. The pebbles and cobbles of the conglomerates are composed of limestone, andesite, metasediments, diorite, and pyroxenite clasts.

The upper member is predominantly composed of polymictic conglomerates and breccias. The clast composition of the upper member shows a higher percentage of granite clasts than the lower member (Figure 3).

Limestone clasts were sampled at the base of the lower member of the GC. The limestone clasts in the samples are sub-angular to sub-rounded and measure from 7 to 50 $\mathrm{cm}$. The textures of the limestone clasts are grainstone, packstone and wackestone with bioclasts, with less than $2 \%$ lithoclasts in a micritic matrix. The bioclasts are represented by skeletal fragments of bivalves, brachiopods, gastropods, echinoderms and foraminifera (Figure 4). Non-skeletal material is less than $2 \%$ and is composed of ooids that vary in diameter from 0.25 to $2.00 \mathrm{~mm}$. The clastic material is sub-angular fine sand composed of quartz, plagioclase and

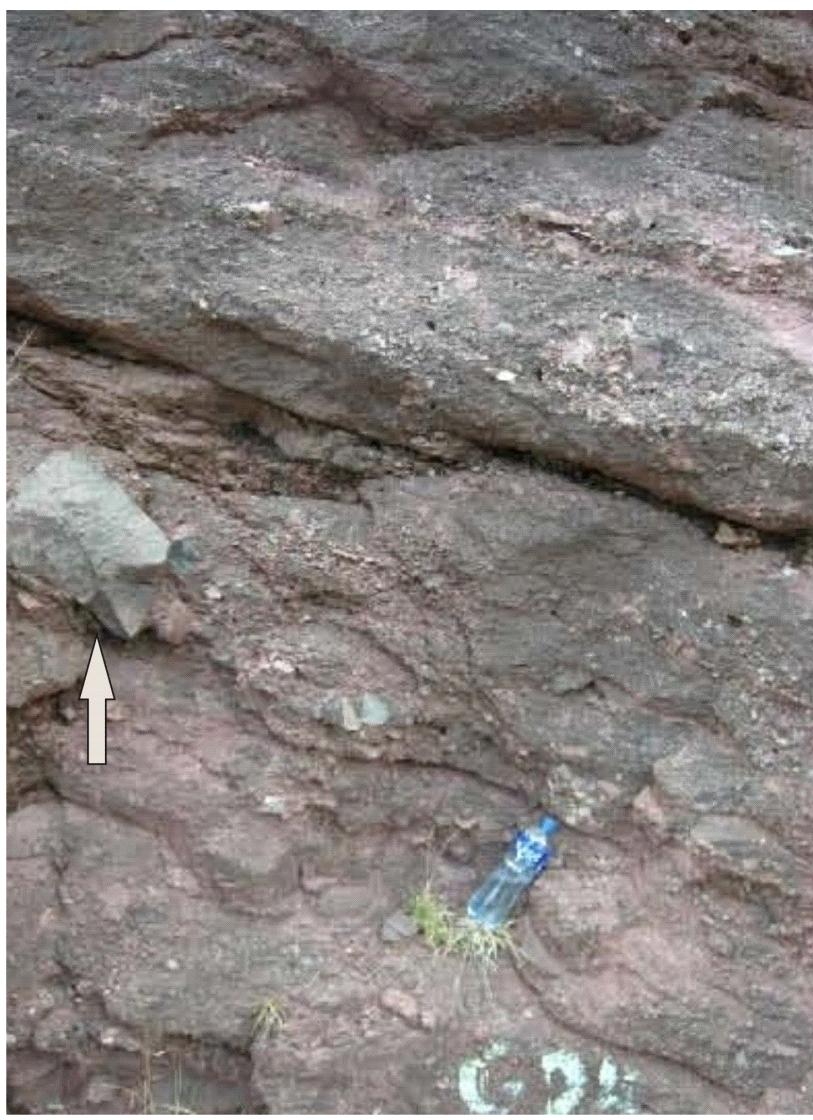

Figure 2. Guanajuato Conglomerate outcrop showing a limestone clast. andesite lytic grains.

\subsection{Foraminiferal assemblage}

The benthic foraminifera contained in the GC clasts are well preserved and were used to determine the age. The principal age markers are the benthic foraminifera Pseudocyclammina lituus (Yokoyama, 1890); Everticyclammina virguliana (Koechlin, 1942); Montsalevia salevensis (Charollais, Brönnimann and Zaninetti, 1987); Neotrocholina valdensis (Reichel, 1955); Andersolina cherchiae (Arnaud-Vanneau, Boisseau and Darsac, 1988); Neotrocholina molesta (Gorbatchik, 1959); Pfenderina neocomiensis (Pfender, 1938); Nautiloculina bronnimanni Arnaud-Vanneau and Peybernès, 1978; and Hechtina praeantiqua Bartenstein and Brand, 1949, which are discussed below.

Pseudocyclammina lituus (Figure 5ac) was first described by Yokoyama (1890) from the Torinosu Limestone in Japan, late Oxfordian, supposedly. This species was reported by Maync (1959) as early Kimmeridgian, and Kobayashi and Vuks (2006) in the Tithonian-Berriasian in the same locality in Japan. Hottinger (1967) documented the occurrence of $P$. lituus in the Kimmeridgian-Portlandian interval in Morocco. It has also been recorded from the Kimmeridgian of the Albacete province (Spain) by Fourcade (1971) and Fourcade and Neumann (1966); in Croatia this fossil occurs in an association dated as latest Oxfordian to earliest Kimmeridgian (Velić et al., 2002). This species has been frequently reported from the Berriasian-Valanginian (Schroeder, 1968; Azema et al., 1977). Pélissié and Peybernès (1982) specified the range of the species as Kimmeridgian to Hauterivian, and Bucur et al. (1995) defined the range from Kimmeridgian to early Valanginian. P. lituus has also been regarded as OxfordianBerriasian from the southern part of Crimea (Krajewski and Olszewska, 2007) and Mexico (Ornelas Sánchez and Alzaga, 1994) and late Kimmeridgian-Valanginian from south-western Bulgaria (Ivanova et al., 2008).

Everticyclammina virguliana (Figure 5 b) is stratigraphically the oldest named species of this genus described by Koechlin (1942) reported from the middle

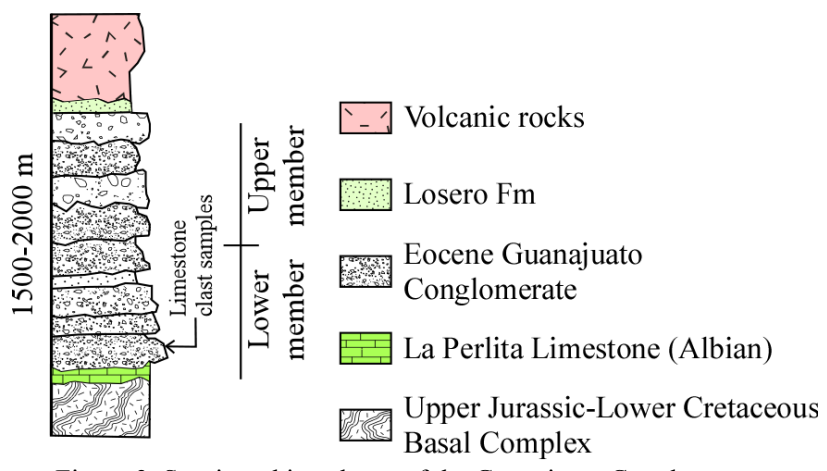

Figure 3. Stratigraphic column of the Guanajuato Conglomerate. 

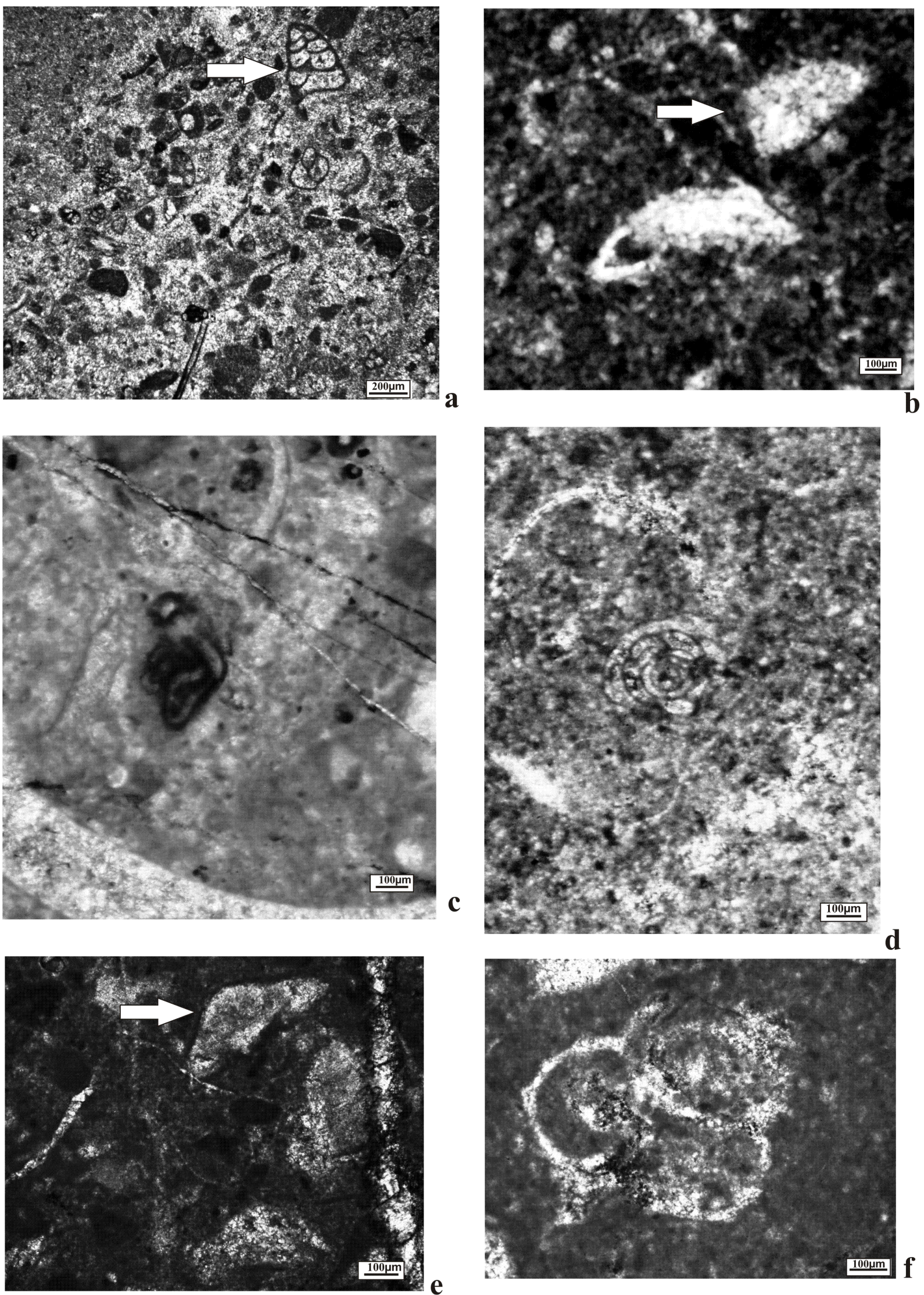

Figure 4. Berriasian-early Valanginian Foraminifera and microfauna from limestone clasts of the Guanajuato Conglomerate. a) Protomarsonella sp. Sample R-M25-09A. b) Andersolina sp., Sample RM-24-09B. c) Ammovertellina sp., Sample RM-24-09C. d) Glomospira sp. Sample RM-24-09B. e) Neotrocholina cf. N. molesta (Gorbatchik, 1959) Sample RM-24-09B. f) Gastropod RM-24-09C. 

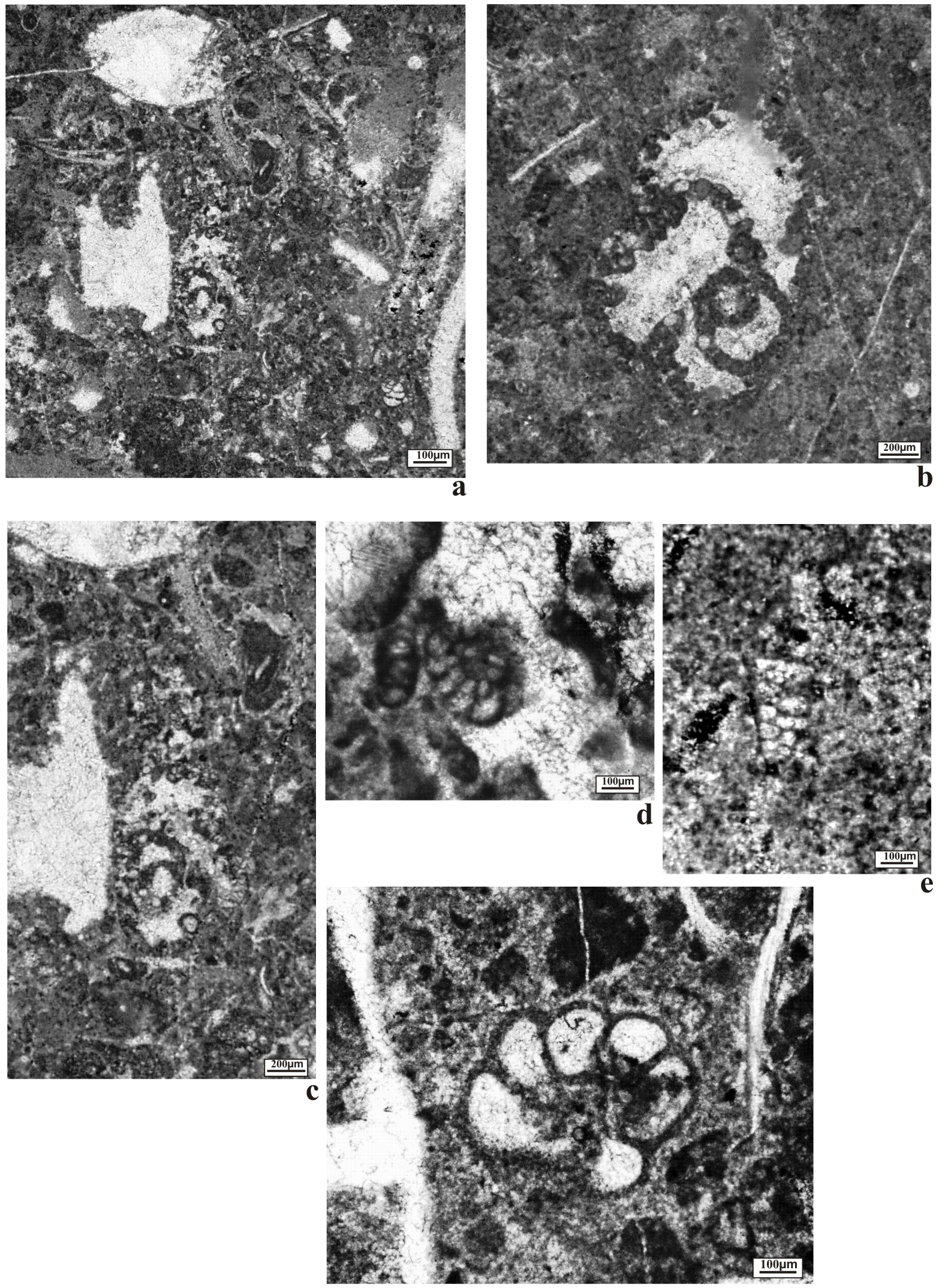

Figure 5. Berriasian-early Valanginian Foraminifera from limestone clasts of the Guanajuato Conglomerate. a, c) Pseudocyclammina lituus (Yokoyama, 1890), Sample RM-24-09A. b) Everticyclammina virguliana (Koechlin, 1942), Sample RM-24-09A. d) Nautiloculina bronnimanni Arnaud-Vanneau and Peybernes, 1978. e) Montaselevia montsalvensis (Charollais, Brönnimann and Zaninetti, 1987), Sample RM-24-09A. f) Pfenderina neocomiensis (Pfender, 1938), Sample RM-24-09A. 
Kimmeridgian, the type specimens from the Berner Jura. Hottinger (1967) recorded this species in the Kimmeridgian of east Morocco. E. virguliana was recorded from Portugal where its first occurrence was at the summit of the Oxfordian. Its distribution is from northern Africa and southern Europe to the Middle East (Ramalho, 1985). Banner and Highton (1990) regarded the species as Kimmeridgian to "Portlandian," but in the earliest Cretaceous (BerriasianValanginian), Everticyclammina virguliana, in equatorial section, is virtually indistinguishable from $E$. kelleri, which is considered to be a Berriasian-Valanginian index.

Montsalevia salevensis (Figure 5e) is regarded as an important age marker. It was illustrated for the first time by Pfender (1938) after being described by Charollais, Brönnimannn and Zaninetti (1986) as Pseudotextulariella salevensis from the lower Valanginian of Saleve near Geneva (Switzerland). The species was later reported from the Valanginian by Schroeder (1968) in Spain; by Fourcade and Raoult (1973) in Algeria; by Azema et al. (1976) in the western Mediterranean region; and Altiner (1991) in Turkey. Zaninetti et al. (1997) in Switzerland, Chiocchini et al. (1988) in Italy and Bucur et al. (1995) in Serbia recorded the species in the late Berriasian-Valanginian interval. Ivanova and Kolodziej (2004) also recorded the species from the Berriasian-Valanginian, from Stramberk-type limestones, the Polish Carpathians, and from Italy (Bruni et al., 2007). Hosseini and Conrad (2008) documented the occurrence of M. salevensis from the Berriasian in SW Iran. A Valanginian M. salevensis Zone was established by Ivanova (1999) in the Balkans.

Neotrocholina valdensis (Figure 6a) was described from the Valanginian of Switzerland by Reichel (1955). It is considered a good marker of the late Berriasian-early Valanginian of NW Anatolia in Turkey (Altiner, 1991), as well as in Italy (Chiocchini et al., 1988), in Romania (Bucur, 1988; Bucur et al., 2004a; Bucur and Săsăran, 2005) and Mexico (Riva-Palacio, 1971). Schlanginweit and Ebli (1999) assigned an early Valanginian age to $N$. valdensis in the northern Alps. The known stratigraphic range of N. valdensis is late Berriasian-Valanginian; the species has been recorded from the Mirdita zone (Albania) in the lowermost Valanginian (Radoičić, 2005).

Neotrocholina molesta (Figure 6c) was originally described from Cretaceous basal deposits in the Crimea region (Gorbatchik, 1959). Later, it was identified in Ukraine, ranging in age from the Tithonian to Barremian (Krajewski and Olszewska, 2007), which agrees with the stratigraphic range of the species presented by Bucur et al. (1995) in Serbia and in northern Iran (Bucur et al., 2013). Pop and Bucur (2001) and Bucur et al. (2004b) found N. molesta in the south Carpathians and Gilău Mountains respectively, in an assemblage dated as BerriasianValanginian. According to Arnaud-Vanneau et al. (1988) $N$. molesta is known from the Berriasian to Barremian (Albian?) interval.

Andersolina cherchiae (Figure 6b) was described by
Arnaud-Vanneau, Boisseau and Darsac (1988). It is regarded as from the Berriasian-early Valanginian in Spain (Ullastre et al., 2002). Hosseini and Conrad (2008) in Zagros Basin (SW Iran) considered the species to be in the interval dated as Berriasian in age. Bucur et al. (1995) documented the occurrence of the species in Serbia in the upper Berriasian-Valanginian. A. cherchiae was also recorded in Austria (Moshammer and Schlanginweit, 1999). Bucur and Săsăran, (2005), and Bucur et al. (2004b) in Turkey found a foraminiferal association that contains different species of Andersolina such as A. cherchiae and N. molesta, which was dated as Early Cretaceous (Berriasian-early Valanginian). Koch et al. (2008) regarded the stratigraphical distribution of $A$. cherchiae in Turkey as limited to Berriasian-early Valanginian. Hosseini and Conrad (2008) and Bucur et al. (2013) recorded Andersolina cherchiae in Iran in an association that they considered as Berriasian age.

Pfenderina neocomiensis (Figure 5f) was illustrated for the first time by Pfender (1938) from the early Valanginian of Provence, and has been frequently reported from the Valangian by Schroeder (1968) and Canerot (1984) in Spain and Bucur et al. (1995) in Serbia. These authors stated that the species is considered a good marker for this age.

Azema et al. (1977) and Bucur and Oros (1987) reported this species from the late Berriasian-early Valanginian, and Zaninetti et al. (1988) recorded the species from the late Berriasian. According to Olszewska (2010), Pfenderina neocomiensis has a stratigraphic distribution from the Berriasian to Hauterivian.

Nautiloculina bronnimanni (Figure 5d) was firstly reported by Arnaud-Vanneau and Peybernès (1978) from the Berriasian to upper Albian interval in the French and Spanish Pyrenees. Canerot (1984) in Spain and Altiner (1991) in Turkey recorded the species from the Berriasian to early Valanginian. Arnaud-Vanneau and Masse (1989) recorded N. bronnimanni from the Berriasian to Aptian in Switzerland in the Valangian-Hauterivian of the Berdiga Formation in Turkey (Bucur et al., 2004a), and the outer Carpathians (Ivanova and Kolodziej, 2010). The species has also been recorded by Radoičić (2005) from the Mirdita zone (Albania) in the lowermost Valanginian. Bucur et al. (1995) defined the stratigraphic range of $N$. bronnimanni from the Berriasian to Aptian.

Hechtina praeantiqua (Figure 7a, c) was described by Bartenstein and Brand (1949) from Hannover (Germany) of older Lower Cretaceous. Later, the species was reported from the uppermost Tithonian-Berriasian by Altiner (1991) in Anatolia, Turkey, and from the outer Carpathians (Ivanova and Kolodziej, 2010) and the Berriasian of Bulgaria (Ivanova, 1999). In addition, some miliolids such as Istriloculina sp., Moesiloculina sp., Ophthalmidium sp. and Spiroloculina sp. (Figure 7) have been reported.

\subsection{Clast Age}

Based on the stratigraphic ranges of the larger benthic 

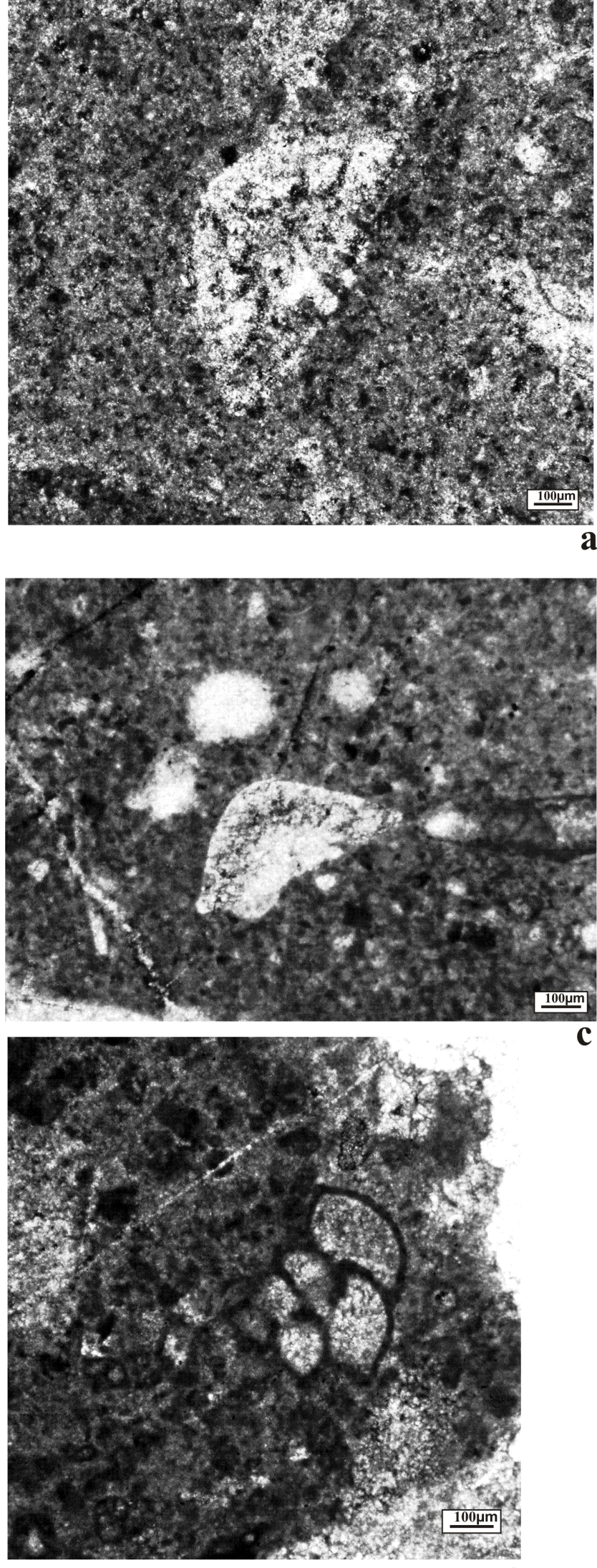
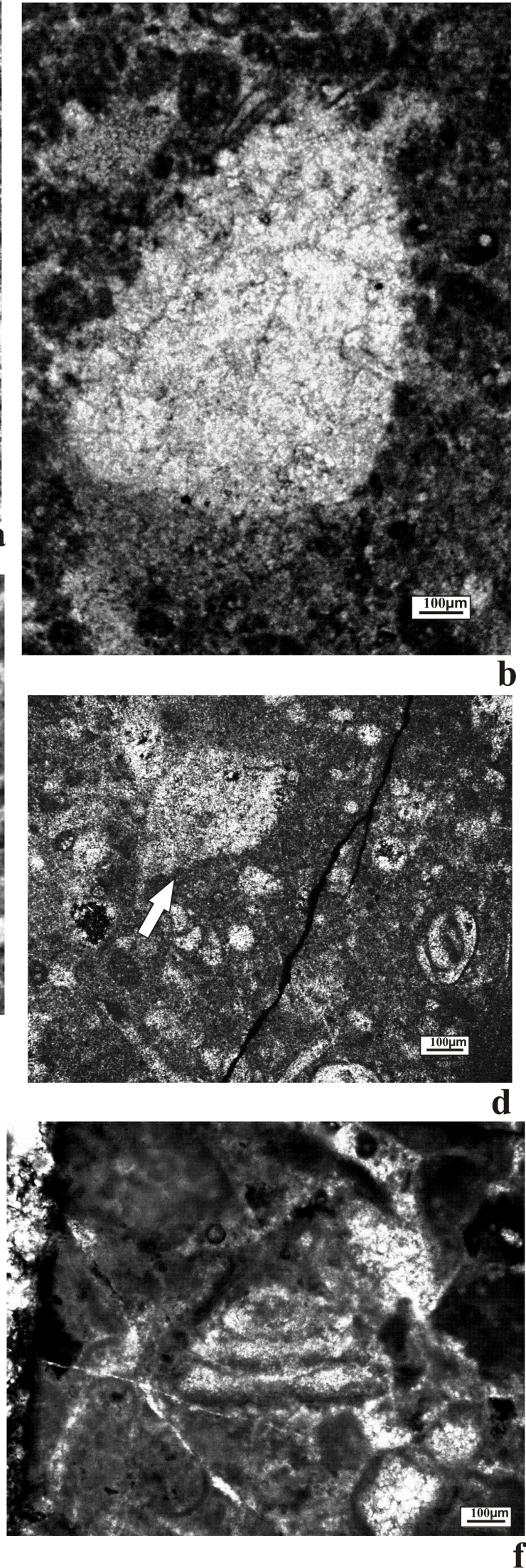

Figure 6. Berriasian-early Valanginian Foraminifera from limestone clasts of the Guanajuato Conglomerate. a) Neotrocholina valdensis (Reichel, 1955), Sample RM-24-09B. b) Andersolina cherchiae (Arnaud-Vanneau, Boisseau and Darsac, 1988), Sample RM-24-09B. c) Neotrocholina molesta (Gorbatchik, 1959), Sample RM-24-09B. d) Andersolina sp., Sample RM-24-09B. e) Textulariopsis sp., Sample RM-24-09B. f) “Trocholina” sp., Sample RM-24-09B. 

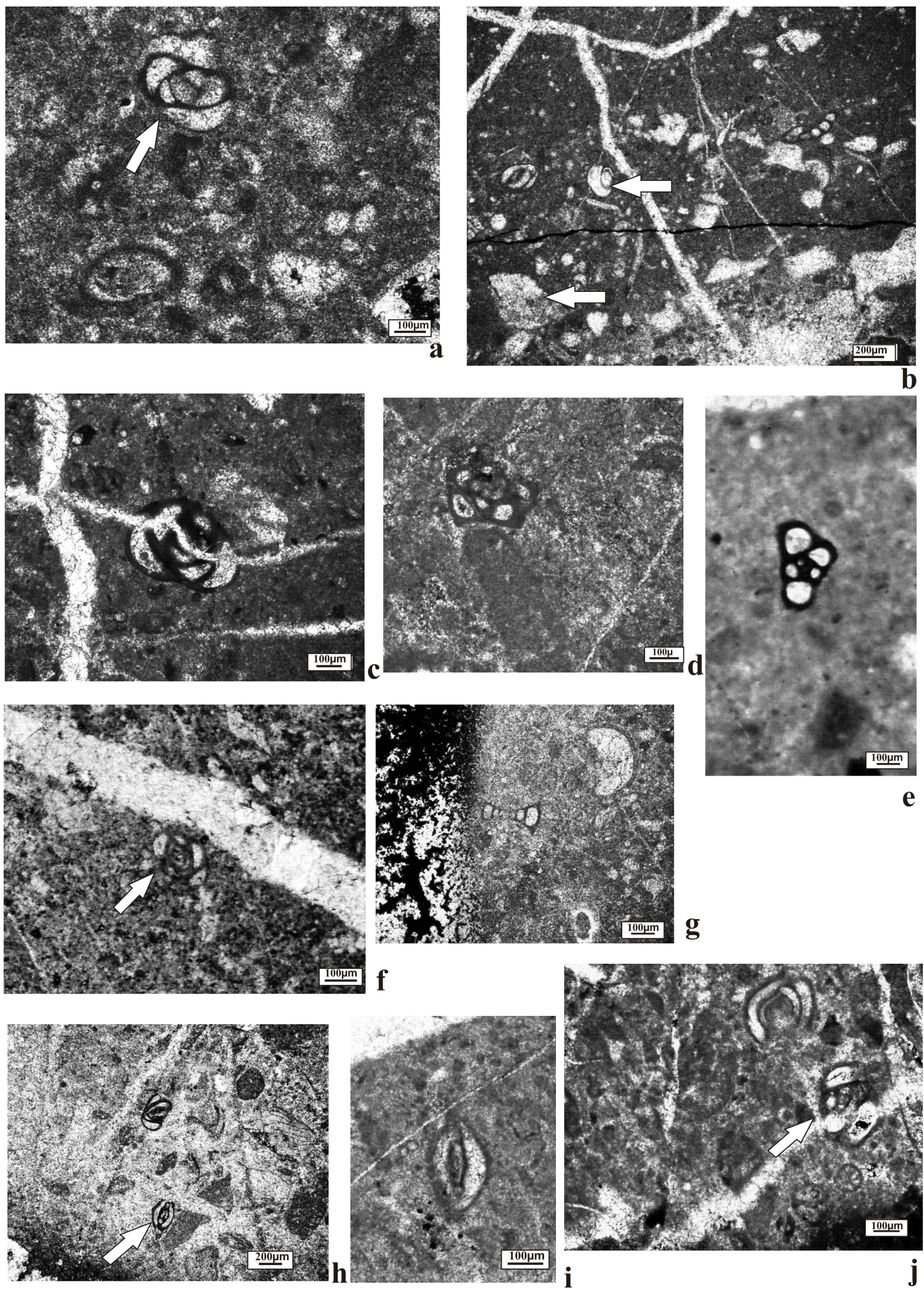

Figure 7. Berriasian-early Valanginian Foraminifera from limestone clasts of the Guanajuato Conglomerate. a, c) Hechtina praeantiqua Bartenstein and Brand, 1949, Sample RM-24-09C. b) Protopeneroplis cf. P. banatica Bucur, 1993, Istriloculina sp., Sample RM-24-09A. d) Moesiloculina sp., Sample RM24-09C. e) Rumanoloculina sp., Sample RM-24-09C. f) Spiroloculina sp., Sample RM-24-09C. g) Miliolid., Sample RM-24-09C. h) Ophthalmidium sp., Sample RM-24-09C. i) Istriloculina sp., Sample RM-24-09C. j) Hechtina praeantiqua Bartenstein and Brand 1949, Spiroloculina sp., Sample RM-24-09C. 
foraminifera, which are well known in the Tethys Realm we assign a Berriasian-early Valanginian age interval to the limestone clasts collected from the Eocene GC.

The dating of the studied assemblage is consistent with the age assignment in other shallow-water platforms in the Mediterranean areas of Europe and the Middle East.

The Andersolina assemblage is considered typical of the earliest Cretaceous Berriasian-early Valangian (ArnaudVanneau, 1985; Bucur et al., 1995; Bucur and Săsăran, 2005).

\subsection{Clast Paleoenvironment}

The foraminiferal assemblage provided a valuable means for interpreting the conditions in which the sediments were deposited.

BouDhager-Fadel (2008) stated that the larger benthic foraminifera that survived the Jurassic-Cretaceous crisis were mostly robust forms such as Pseudocyclammina and Everticyclammina. These species were observed in the studied material, indicating that they persisted until the Berriasian $\neg$ Valanginian, inhabiting a shallow marine environment (Banner and Whittaker, 1991).

According to Szydlo (2005), the flattened or conical tests belonging to the trocholinid group, such as those of Andersenolina, Trocholina, Neotrocholina, prefer peri-reefal environments (Arnaud-Vanneau et al., 1988; Neagu, 1995). According to Mancinelli and Coccia (1999) the palaeoecologic significance of the Trocholinas is that the increase in these benthic foraminifera seems to have been influenced by particular environmental conditions characterized by strong water energy. The AndersenolinaNeotrocholina assemblage was found in the samples analyzed. Therefore, we infer that the environment could be similar to that proposed by these authors.

Another foraminiferal association was composed of miliolids such as Istriloculina sp., Moesiloculina sp., Quinqueloculina sp. and Spiroloculina sp. This association inhabits a very shallow, low-energy environment with fine sediments, subject to fluctuations of temperature and salinity, as has been suggested by other authors (Gräfe, 2005; Dragastan et al., 2005; Amodio, 2006).

\subsection{Paleobiogeography}

During the Jurassic, with the breakup of Pangea, Laurasia split from Gondwana forming a marine route between the Tethys and the Pacific Ocean. It is possible to establish evidence of this marine connection from the Late Jurassic using the occurrences of coincident faunal assemblages.

Although most of the benthic foraminifera of the Cretaceous had not evolved yet, and with very few new appearances in the Berriasian (5\%), nearly all the benthic foraminifera were Jurassic survivors and the majority was restricted to the Tethys Realm, colonizing all Early
Cretaceous reefs. Most forms continued through the Valanginian (BouDagher-Fadel, 2008). All the Berriasianearly Valangian benthic foraminifers identified from the limestone clasts of the GC include Tethysian taxa correlated with other localities in the Mediterranean area. The finding of this Tethysian foraminiferal assemblage provides information about their presence in a zone regarded as being of the Pacific Domain.

\section{Discussion}

The occurrence of a Berriasian-early Valanginian shallow-water foraminiferal association in the clasts of the GC has not been previously reported in the literature, so the significance of this finding is that it suggests the existence of a shallow-water platform in the Arperos Basin. According to the age assigned to the GC limestone clasts, we propose that the shallow-water limestone could correlate with the top of the volcano-sedimentary association of the Arperos Basin.

In paleogeographic reconstructions, only the presence of basin deposits within the Arperos Assemblage has been considered in the literature; however, Echegoyén Sánchez (1978) described the Esperanza Formation as containing limestone, but without giving a detailed description. Martini et al. (2010) reported the Valenciana Formation "as a Lower Cretaceous calcareous debris, which results by erosion of widespread carbonate platform developed on Mexican mainland."

In this paper, we suggest that the shallow-water assemblage of the GC limestone clasts must have come from the calcareous constructions located in the Arperos Basin, since it is the nearest source. The provenance of the clasts being from other platform deposits appears very unlikely because they are distant and of different age. For example, along the Pacific margin, the majority of shallow-water deposits are younger. Several sites with shallow-water deposits have been reported from the states of Guerrero, Michoacán, Jalisco, Colima, Sonora and Baja California. These deposits span from the early Aptian to the Cenomanian (Omaña et al., 2012 compilation). In northeastern Mexico, the Cupido Plarform developed in the Barremian-Aptian interval, while the Aurora Formation was deposited in the mid-late Albian (Wilson and Ward, 1993; Lehmann et al., 2000). During the Albian, the border around the deep central part of the Gulf of Mexico received widespread carbonate deposition. Examples are the Valles-San Luis Potosí Platform, (Bonet, 1956, Carrillo-Bravo, 1971; Wilson and Ward, 1993; Basáñez-Loyola et al., 1993; Omaña et al., 2013); the Tuxpan Platform (Wilson and Ward, 1993); and the Córdoba Platfom (Ortuño-Arzate et al., 2003). These platforms have been dated as Albian-Cenomanian. In Chiapas, a Late Jurassic shallow-water foraminiferal association was recorded by Michaud (1987) and Ornelas and Hottinger (2006). Deposits of Albian-Cenomanian age (Michaud, 1987; Rosales Domínguez et al., 1997) have also 
been reported from the Sierra Madre limestone platform.

The shallow-water limestone clasts of the $\mathrm{CG}$ are in part correlated to the Torinosu Limestone, which represents a carbonate platform deposited in a fore-arc basin developed on the Jurassic-Berriasian accretionary complex in Japan (Matsuoka, 1992), an environment probably similar to that of the limestone clasts studied here.

\section{Conclusions}

A benthic foraminiferal and lithofacies study was carried out on limestone clasts contained in the mid-Eocene Guanajuato Conglomerate.

We documented the existence of a carbonate shallowwater platform based on the benthic foraminiferal association. In addition, the size and the angular, sub-rounded shape of the clasts indicate that they originated from a nearby source within the framework of the Arperos Basin.

Thirteen benthic foraminiferal species with a wide paleobiogeographic distribution within the Tethys realm were identified from the limestone pebbles of the Guanajuato Conglomerate.

The foraminiferal assemblages of these clasts contain many stratigraphically significant species of benthic foraminifera indicating a late Berriasian to early Valanginian age.

The benthic foraminiferal association enables a paleoenvironmental interpretation of the clasts that suggests two environments in the shallow-water platform, one association that inhabited the high-energy zone and another that occupied a quiet water environment.

The occurrence of these shallow-water limestone clasts suggests the existence of a shallow-water platform deposit of late Berriasian to early Valanginian age correlated to the Arperos Basin deposits.

\section{Acknowledgements}

We are greatly indebted to the Instituto de Geología of the Universidad Nacional Autónoma de México and to the Departamento de Minas, Metalurgia y Geología of the Universidad de Guanajuato for supporting this study.

We are very grateful to Dr. Gilberto Silva Romo (Facultad de Ingeniería, UNAM) for the valuable comments and suggestions revising an earlier version of the manuscript.

We thank Dr. Michelangelo Martini (Instituto de Geología, UNAM) for the detailed revision and the important remarks that greatly improved this paper. We also thank Dr. Carmen Rosales (Independent Consultant) for revising the manuscript and her constructive recommendations and Barbara Martiny for revision of the English.

\section{References}

Altiner, D., 1991, Microfossil biostratigraphy (mainly foraminifers) of the Jurassic-Lower Cretaceous carbonate succession in north-western Anatolia (Turkey): Geologica Romana, 27, 167-215.

Amodio, S., 2006, Foraminifera diversity changes and paleoenvironmental analysis: The Lower Cretaceous shallow-water carbonates of San Lorenzello, Campanian Apennines, southern Italy: Facies, 52, 53-67.

Aranda-Gómez, J.J., McDowell, F.W., 1998, Paleogene extension in the southern Basin and Range Province of Mexico: Syndepositional tilting of Eocene red beds and Oligocene volcanic rocks in the Guanajuato mining district: International Geology Review, 40, 116-134.

Arnaud-Vanneau, A., Boisseau, T., Darsac, C., 1988, Le genre Trocholina Paalzow 1922 et ses principales espèces au Crétacée: Revue de Paléobiologie, vol. Spéc. 2, Benthos '86, 353-377.

Arnaud-Vanneau, A., Peybernès, B., 1978, Les représentants éocrétacés du Genre Nautiloculina Mohler, 1938 (Foraminifera, Fam. Lituolidae?) dans les châines subalpines septentrionales (Vercors) et les Pyrénées Franco-Espagnoles. Révision de Nautiloculina cretacea Peybernès, 1976 et description de Nautiloculina bronnimanni n. sp.: Geobios, $11(1), 67-81$.

Azema, J., Fourcade, E., Jaffrezo, M., Thieuloy, J-P., 1976, Sur l'âge Valanginien inférieur de la biozone à Valdanchella miliani (foraminifères): Intérêt pour la stratigraphie dans le domaine méditerranéen occidental: Comptes Rendus de l'Académie des Sciences de Paris, D 282, 1411-1414.

Azema, J., Chabrier, G., Fourcade, E., 1977, Nouvelles données stratigraphiques et paléogéographiques sur le Portlandien et le Néocomien de Sardaigne: Revue de Micropaléontologie, 20 (3), 125-139.

Banner, F.T., Highton, J., 1990, On Everticyclammina Redmond (Foraminifera), especially E. kelleri (Henson): Journal of Micropalaeontology, 9 (17), 1-14.

Banner, F.T., Whittaker, J.E., 1991, Redmond's "new lituolid Foraminifera" from the Mesozoic of Saudi Arabia: Micropaleontology, 37, 41-59.

Bartenstein, B.H., Brand, E., 1949, New genera of Foraminifera of the Lower Cretaceous of Germany and England: Journal of Paleontology, 23 (6), 669-672.

Basáñez-Loyola, M.A., Fernández-Turner, R., Rosales-Domínguez, C., 1993, Cretaceous Platform of Valles-San Luis Potosí, Northeast central Mexico, in Simó, J.A., Scott, R.W., Masse, J.P. (Eds.), Cretaceous Carbonate Platforms: American Association of Petroleum Geologists Memoir, 56, 51-59.

Bonet, F., 1956, Zonificación microfaunística de las Calizas Cretácicas del Este de México: Boletín de la Asociación Mexicana de Geólogos Petroleros 8, 389-489.

Botsford, C.W., 1909, The Zacatecas district and its relation to Guanajuato and other camps: The Engineering and Mining Journal, 87, $1227-1228$.

BouDhager-Fadel, M., 2008, Evolution and geological significance of larger benthic foraminifera, in Wignall, P.B. (Ed.), Developments in Palaeontology and Stratigraphy 21, Elsevier Amsterdam, 515 p.

Bucur, I.I., 1993, Les représentants du genre Protopeneroplis Weynschenk dans les dépôts du Crétacé Inférieur de la Zone de ResitaMoldova Nouă (Carpathes Méridionales) de Roumania: Revue de Micropaléontologie, 36 (3), 213-223.

Bucur, I.I., Conrad, M.A., Radoicic, R., 1995, Foraminifers and calcareous algae from Valanginian limestones in the Jerma River Canyon, Eastern Serbia: Revue de Paléobiologie, 14 (2), 349-377.

Bucur, I.I., Săsăran, L., Săsăran, E., Schuller, V., 2004a, Micropaleontological study of the limestone olistoliths within the Upper Cretaceous wildflysh from Hăşdate (eastern border of the Gilău Mountains): Acta Paleontologica Romaniae, 4, 55-67.

Bucur, I.I., Koch, R., Kirmaci, R., Tasli, K., 2004b, Foraminifères du Jurassique Supérieur te du Crétacé Inférieur (Calcaire de Berdiga) de Kircaova (région de Kale-Gümüshane, NE Turquie): Revue de Paléobiologie, 23 (1), 2009-225. 
Bucur, I.I., Oros, 1987, Some microfacial peculiarities of the Lower Cretaceous deposits from Ilidia (Resita Zone, South Carpathians): Dari de Seama ale Sedintelor Institutul de Geologie si Geofizica, 72-73 (3), 37-52.

Bucur, I.I., Reza, R.M., Senowbari-Daryan, B., 2013, Early Cretaceous benthic microfossils from the eastern Alborz and western Kopet Dagh (northern Iran) and their stratigraphic significance: Acta Paleontologica Romaniae, 9, 23-37.

Bucur, I.I., Săsăran, E., 2005, Micropaleontological assemblages from the Upper Jurassic-Lower Cretaceous deposits of Trascău Mountains and their biostratigraphic significance: Acta Paleontologica Romaniae, $5,27-38$.

Bruni, R., Bucur, I., Preat, A., 2007, Uppermost Jurassic-Lowermost Cretaceous carbonate deposits from Fara San Martino (Maiella, Italy): biostratigraphic remarks: Studia Universitatis Babeş-Bolyai, Geologia 52 (2), 45-54.

Canerot, J., 1984, Fluctuations marines et évolution: exemple du Néocomien des Ibérides orientales, in Oertli, H.J. (ed.), Benthos 83-2nd, International Symposium on Benthic Foraminifera. Elf Aquitaine, Esso Rep and Total CFP, 131-139.

Carrillo-Bravo, J., 1971, La Plataforma Valles-San Luis Potosí: Boletín de la Asociación Mexicana de Geólogos Petroleros, 23, 1-102.

Charollais J., Brönnimannn, P., Zaninetti, L., 1966, Troisième note sur les foraminifères du Crétacé Inférieur de la région genevoise: Remarques stratigraphiques et description de Pseudotextularia salevensis n. sp.; Haplophragmoides joukowsky n. sp.; Citaella ?favrei n. sp.: Archives des Sciences S.P.H.N. Genève, 19 (1), 23-48.

Chiocchini, M., Mancinelli, A., Marucci, C., 1988, Distribution of Benthic Foraminifera and Algae in the Latinum-Abruzzi Carbonate Platform Facies (Central Italy) during Upper Malm-Neocomian: Revue de Paléobiologie, Vol. Spécial 2, 219-227.

Chiodi, M., Monod, O., Busnardo, R., Gaspar, D., Sánchez, A., Yta, M., 1988, Une discordance antéalbienne datée par une faune d'ammonites et de brachiopodes de type téthysien au Mexique: Geobios, 21, 125-135.

Corona-Chávez, P., 1988, Análisis estratigráfico estructural de la porción centro-sur de la Sierra de Guanajuato, México: México, Instituto Politécnico Nacional, Escuela Superior de Ingeniería y Arquitectura, tesis de licenciatura, $60 \mathrm{p}$.

Dávila Alcocer, V.M., Martínez Reyez, J., 1988, Una edad Cretácica para las rocas basales de la Sierra de Guanajuato, Simposio sobre la Geología de la Sierra de Guanajuato Programa y Resúmenes: Universidad Nacional Autónoma de México, Instituto de Geología, 19-20.

Dragastan, O.N., Popescu, I.S., Popescu, A., 2005, Early Cretaceous microfacies and algae from the central-eastern sectors of Moesinian carbonate platform: Acta Paleontologica Romaniae, 5, 141-162.

Dürr, S.B., 1994, Quick estimation of pebble volumes: Journal of Sedimentary Research, 64, 677-679.

Echegoyén Sánchez, J., 1978, Yacimientos minerales de la Sierra de Arperos y Comanja, Guanajuato: Geomimet, 93, 44-73.

Edwards, J.D., 1955, Studies of some early Tertiary red conglomerates of central Mexico: U.S. Geological Survey, Professional Paper, (264-H), 183p.

Ferrusquía-Villafranca, I., 1987, Reubicación geocronología del Conglomerado Guanajuato basada en nuevos mamíferos, in Programa, resúmenes y guía de excursión del simposio sobre la geología de la región de la Sierra de Guanajuato, Guanajuato, Gto.: Universidad Nacional Autónoma de México, Instituto de Geología, 21-23.

Fourcade, E., 1971, Le Jurassique dans la partie orientale des zones externes des Cordillères Bétiques: les confins de Prebétique et des Chaînes Ibériques entre le Rio Mundo et le Rio Jucar (Stratigraphie, Zones á Foraminifères et Paléogéographie): Cuadernos Geología Ibérica, 2, 157-182.

Fourcade, E., Neumann, M., 1966, A propos des genres Labyrinthyna Weynschenk, 1951 et Lituosepta Cati, 1959: Revue de Micropaléontologie, 8 (4), 233-239.

Fourcade, E., Raoult, J.F., 1973, Crétacé du Kef Hahouner et position stratigraphique de Ovoalveolina reicheli de Castro (série septentrionale du môle néritique du Constantinois, Algérie): Revue de Micropaléontologie, 15, (4) 227-246.

Freydier, C., Martinez, R.J., Lapierre, H., Tardy, M., Coulon, C., 1996, The Early Cretaceous Arperos oceanic basin (western Mexico): Geochemical evidence for a seismic ridge formed near a spreading center: Tectonophysics, 259, 343-367.

Gorbatchik, T.N., 1959, Noviie vidi foraminiferi iz nijnevomela Krima i Servo-zapadno Kavkaza: Paleontologicheskii Zhurnal, 1, 78-91.

Gräfe, K-U., 2005, Late Cretaceous benthic foraminifers from the BasqueCantabrian Basin, northern Spain: Journal of Iberian Geology, 31, (2), 277-298.

Guiza, R., 1949, Estudio geológico del distrito minero de Guanajuato: Instituto Nacional para la investigación Recursos Minerales (México), Boletín 22, 75p.

Hernández-Silva, G., Solorio-Munguía, G., Vasallo-Morales, L., FloresDelgadillo, L., Maples-Vermeersch, M., Hernández-Santiago, D., Alcalá-Martínez, R., 2000, Dispersión de Ni y Cr en sedimentos y suelos superficiales derivados de piroxenita, serpentinas y basaltos de la cuenca de San Juan Otates, Estado de Guanajuato, México: Revista Mexicana de Ciencias Geológicas, 17 (2), 125-136.

Hosseini, S.A., Conrad, M.A., 2008, Calcareous algae, foraminifera and sequence stratigraphy of the Fahliyan Formation at Kuh-e-Surmeh (Zagros Basin, SW of Iran): Geologia Croatica, 61 (2-3), 215-237.

Hottinger, L., 1967, Foraminifères imperforés du Mésozoïque marocain: Notes et Mémoires du Service géologique du Maroc, 209, 1-168.

Ivanova, D., 1999, Middle Callovian to Valanginian microfossil biostratigraphy in the west Balkan Mountain, Bulgaria (SE Europe): Acta Paleontologica Romaniae 2, 231-236.

Ivanova, D., Kolodziej, B., 2004, New foraminiferal data on the age of Stramberk-Type limestones, Polish Carpathian: Comptes Rendus de l'Académie Bulgare des Sciences, 57 (12), 69-74.

Ivanova, D., Kolodziej, B., Koleva-Rekalova, E., Roniewicz, E., 2008, Oxfordian to Valanginian paleoenvironmental evolution on the western Moesian carbonate platform: Annales Societatis Geologorum Poloniae, 78, 65-90.

Ivanova, D., Kolodziej, B., 2010, Late Jurassic-Early Cretaceous foraminifera from Štramberk-type limestones, Polish Outer Carpathians: Studia Universitatis Babeş-Bolyai, Geologia, 55 (2), 3-31.

Kobayashi, F., Vuks, V.J., 2006, Tithonian-Berriasian foraminiferal faunas from the Torinosu-type calcareous blocks of southern Kanto Mountains Japan: their implications for post-accretionary tectonics of Jurassic to Cretaceous terranes: Geobios, 39, 883-843.

Koch, R., Bucur, I.I., Kirmaci, M.Z., Eren, M., Tasli, K., 2008, Upper Jurassic and Lower Cretaceous carbonate rocks of the Berdiga Limestone-Sedimentation on a bound platform with volcanic and episodic siliciclastic influx. Biostratigraphy, facies and diagenesis (Kircaova, Kale-Gümüshane area, NE-Turkey): Neues Jahrbuch für Geologie und Paläontologie Abhandlungen, 247, 23-61.

Koechlin, E., 1942, Pseudocyclammina virguliana n. sp. aus den VirgulaMergelndes des Berne Jura: Eclogae Geologicae Helvetiae, 35, 159-199.

Krajewski, M., Olszewska, B., 2007, Foraminifera from the Late Jurassic and Early Cretaceous carbonate platform facies of the southern part of the Crimea Mountains, Southern Ukraine: Annales Societatis Geologorum Poloniae, 77, 291-311.

Lapierre, H., Ortiz, L.E., Abouchami, W., Monod, O., Coulon, C., Zimmermann, J.L., 1992, A crustal section of an intraoceanic island arc: the Late Jurassic-Early Cretaceous Guanajuato magmatic sequence, central Mexico: Earth and Planetary Science Letters, $108,61-77$.

Lehmann, C., Osleger, D., Montañez, I., 2000, Sequence stratigraphy of Lower Cretaceous (Barremian-Albian) carbonate platforms of northeastern Mexico: Regional and Global correlations: Journal of Sedimentary Research, 70 (2), 373-391.

Mancinelli, A., Coccia, B, 1999, Trocholinas from Mesozoic platform sediments of Central-Southern Apennines: Revue de Paléobiologie, 18 (1), 147-171. 
Martini, M., Mori L, Solari L, Centeno-García E., 2011, Sandstone provenance of the Arperos Basin (Sierra de Guanajuato, central Mexico): Late Jurassic-Early Cretaceous back-arc spreading as the foundation of the Guerrero terrane: The Journal of Geology, $119,597-617$.

Maync, W., 1959, Deux nouvelles espèces Crétacées du genre Pseudocyclammina (Foraminifères): Revue de Micropaléontologie, 1, 179-189.

Michaud, F., 1987, Stratigraphie et paléogeographie du Mesozoique du Chiapas (Sud Est du Mexique: Académie de Paris Université Pierre et Marie Curie. Mémoires de Sciences de la Terre, 87, 298 p.

Moshammer, B., Schlagintweit, F., 1999, The Ernstbrun Limestone (Lower Austria): new data on biostratigraphy and applied geology: Abhandlungen der Geologischen Bundesanstalt, 56 (2), 553-565.

Neagu, T., 1995, Early Cretaceous Trocholina group and some related genera from Romania. Part II: Revista Española de Micropaleontología, 27 (2), 5-40.

Nieto-Samaniego, A.F., Macías-Romo, C., Alaníz-Álvarez, S.A., 1996, Nuevas edades isotópicas de la cubierta volcánica cenozoica de la parte meridional de la Mesa Central, México: Revista Mexicana de Ciencias Geológicas, 13 (1), 117-122.

Olszewska, B., 2010, Microfossils of the Upper Jurassic and Lower Cretaceous formations of the Lublin Upland (SE Poland) based on thin sections studies: Polish Geological Institute Special Papers, $23,1-54$.

Omaña, L, Centeno García, E., Buitrón Sánchez, B.E., 2012, Comunidades bentónicas de plataforma del Cretácico asociadas a arcos magmáticos en la parte occidental de México: Paleontología Mexicana, 62, $121-132$.

Omaña, L., López Doncel, R., Torres Hernández J.R., Alencáster, G., 2013, Biostratigraphy and paleoenvironment of the Cenomanian/Turonian boundary interval based on foraminifera from the western part of the Valles-San Luis Potosí Platform, Mexico: Micropaleontology, $58(6), 457-485$.

Ornelas Sánchez, M., Alzaga Ruiz, H., 1994, Variaciones del nível del mar y su influencia sobre la microflora y la microfauna del Jurásico Superior-Cretácico Inferior de Chiapas: Boletín de la Asociación Mexicana de Geólogos Petroleros, 44 (1), 16-35.

Ornelas Sánchez, M., Hottinger, L., 2006, Upper Jurassic Lituolids in the Sierra de Chiapas (Mexico) and their relation to the Tethys: Anuário do Instituto de Geociências, 29 (1), 351-352.

Ortiz Hernández, L.E., Acevedo Sandoval, O.A., Flores Castro, K., 2003, Early Cretaceous intraplate seamounts from Guanajuato, Central Mexico: geochemical and mineralogical data: Revista Mexicana de Ciencias Geológicas, 30, 27-40.

Ortiz Hernández, L.E., Chiodi, M., Lapierre, H., Monod, O., Calvet, P., 1992, El arco intraoceánico alóctono (Cretácico Inferior) de Guanajuato-Características petrográficas, geoquímicas, estructurales e isotópicas del complejo filoniano y de las lavas basálticas andesíticas asociadas; implicaciones geodinámicas: Universidad Nacional Autónoma de México, Instituto de Geología Revista, 9 (2), 126-145.

Ortuño-Arzate, S., Ferket, H., Cacas, M.C., Swennen, R., Roure, F., 2003, Late Cretaceous carbonate reservoirs in the Córdoba Platform and Veracruz Basin, Eastern Mexico, in Bartolini, C., Buffer, R.T., Blackwede (eds.) The Circum Gulf of Mexico and the Caribbean: Hydrocarbon habitats basin formation and plate tectonics: American Association of Petroleum Geologists Memoir, 78, 476-514.

Pélissié, T., Peybernès B., 1982, Étude micropaléontologique du Jurassique Moyen-Supérieur du Causse de Limogne (Quercy): Revue de Micropaléontologie, 25 (2), 111-132.

Pfender, J., 1938, Les Foraminifères du Valanginien provençal: Bulletin de la Société Géologique de France, 5 (8), 231-142.

Puy Alquiza M.J., Miranda-Avilés R., Salazar Hernández C., Vega González M., Cervantes J., 2013, Characterization petrophysical of the Losero Formation in the historical architecture of the Guanajuato city, Mexico: Revista Ingeniería Investigación y Tecnología, XIV (2), 191-202.
Radoičić, R., 2005, New Dasycladales and microbiota from the lowermost Valanginian of the Mirdita Zone: Annales Géologiques de la Péninsule Balkanique, 66, 27-53.

Ramalho, M.M., 1985, Considération sur la biostratigraphie du Jurassique Supérieur de l'Algarve Oriental (Portugal): Serviços Geologicos de Portugal, 67, 41-56.

Randall-Roberts J.A., Saldaña E., Clark, K.F., 1994, Exploration in a Volcano-Plutonic Center at Guanajuato, México: Economic Geology, 89, 1722-1751.

Reichel, M., 1955, Sur une Trocholine du Valanginien d'Arzier: Eclogae Geologicae. Helvetiae, 48 (2), 396-408.

Riva-Palacio, E., 1971, Trocholina valdensis (Reichel) dans le Crétacé Inférieur du Mexique: Revue de Micropaléontologie, 14 (2), $102-105$.

Rosales-Domínguez, C., Bermúdez, I.C., Aguilar, M., 1997, Mid and Upper Cretaceous foraminiferal assemblages from the Sierra de Chiapas: Cretaceous Research, 18, 697-712.

Schlagintweit, F., Ebli, O., 1999, New results on microfacies, biostratigraphy and sedimentology of Late Jurassic-Early Cretaceous platform carbonates of the northern calcareous Alpes. Part 1 Tessenstein Limestone Plassen Formation: Abhandlungen der Geologischen Bundesanstalt, 56 (2), 379-418.

Schroeder, R., 1968, Sobre algunos foraminíferos del Valanginiense de la Sierra de Valdencha (Provincia de Castellón): Boletín de la Real Sociedad Española de Historia Natural (Geológica), 66, 311-318.

Szydlo, A., 2005, Benthic foraminiferal morphogroup and taphonomy of the Cieszyn beds (Tithonian-Neocomian Polish Outer Carpathian): Studia Geologica Polonica, 124, 199-214.

Tardy, M, Lapierre, H., Boudier, J-L., Yta, M., Coulon, Ch., 1991, The Late Jurassic-Early Cretaceous arc of western Mexico (Guerrero terrane); origin and geodynamic evolution: Universidad Nacional Autónoma de México: Instituto de Geología, Convención sobre la evolución geológica de México, I Congreso Mexicano de Mineralogía, Memoria, 213-215.

Ullastre, J., Schroeder, R., Masriera, A., 2002, Sobre la estratigrafía del singular corte de la Roca de Narieda (parte S de la serie del Cretácico Inferior de Organya). Pirineo catalán, España: Treballs del Museu de Geologia de Barcelona, 11: 67-95.

Velić, I., Tisljar, J., Vlahović, I., Velić, J., Koch, G., Maticec, D., 2002, Paleogeographic variability and depositional environments of the Upper Jurassic carbonate rocks of Velika Kapela Mt. (Gorski Kotar Area, Adriatic Carbonate Platform, Croatia): Geologia Croatica, 55 (2), 121-138.

Wandke, A., Martínez J., 1928, The Guanajuato mining district, Guanajuato, Mexico: Economic Geology, 23, 1-44.

Wilson, J.L., Ward, W.C., 1993, Early Cretaceous carbonate platforms of northeast and east central Mexico, in Simó, J.A., Scott, R.W., Masse, J.P. (Eds.), Cretaceous Carbonate Platforms. American Association of Petroleum Geologists Memoir 56, 35-49.

Yokoyama, M., 1890, Foraminiferen aus dem Kalskteine von Torinosu und Kompira. In Naumann, E. and Neumayr, M., Zur Geologie und Paläontologie von Japan: Denkschriften der Kaiserlichen Akademie Wissenchaften, Wien, Mathematish-Naturwissen-schaftliche Classe, $57,20$.

Zaninetti, L., Salvini-Bonnard, G., Decrouez, D., 1987, Montsalevia, n. gen. (Montsaleviidae, n. fam. Foraminifère), dans le Crétacé Inférieur (Berriasien moyen-Valanginien) du Mont Salève et du Jura Méridional (Haute-Savoie, France). Note préliminaire: Revue de Paléobiologie, 6 (1), 165-168.

Zaninetti, L., Charollais, J., Clavel, B., Decrouez, D., Salvinni-Bonnard, G., Steinhauser, N., 1988, Quelques remarques sur les fossiles du Salève (haute Savoie, France): Archives des Sciences SPHN, Genève, 41 (1), 43-63.

Manuscript received: June 3, 2014.

Corrected manuscript received: October 6, 2014.

Manuscript accepted: October 20, 2014. 